\title{
A nação de Renan*
}

Renato de Mello**

RESUMO : Tradução da conferência Qu'est-ce qu'une nation? de Ernest Renan, feita em 11 de março de 1882 no grande anfiteatro da Sorbonne, precedida de uma apresentação crítica.

No final do Século XIX, disputas territoriais entre Estados, sobretudo entre a França e a Alemanha por causa da Alsace-Lorraine, deram origem a diversas considerações filosóficas sobre a nação. Uma delas, a de Ernest Renan, foi tida por alguns intelectuais como a mais justa e democrática expressão de uma concepção francesa do problema. A única realmente aceitável. Trata-se da conferência $Q u$ 'est-ce qu'une nation? feita em 11 de março de 1882 no grande anfiteatro da Sorbonne.

Renan, filósofo e historiador das religiões, já era, naquela época, famoso por seu texto Vie de Jésus (1863), que provocou grande escândalo nos meios religiosos e o levou a ser suspenso como professor do Collège de France pelas autoridades imperiais. Depois da queda do Império, Renan voltou a lecionar e recebeu várias honrarias da República. Suas convicções, ao mesmo tempo católicas e anticlericais, fizeram dele uma espécie de formador de opiniões. Seu discurso sobre 
a nação passou a refletir, assim, as idéias oficiais, ou pelo menos não lhe eram contrárias.

Hoje, o pensamento de Renan tornou-se a expressão de uma das raras concepções aceitáveis de nação - haja vista que $Q u$ 'est-ce qu'une nation? foi recentemente republicado em vários países. Mas, o que se entende por nação? O que Renan entende por nação? A maior parte do texto é composta de uma série de propostas sobre diversas organizações políticas, principalmente da Antigüidade e da Idade Média, além do exame de várias teorias que, às vezes, ele contesta. Renan critica veementemente as teorias que tratam da "raça", mas se mostra muito evasivo sobre a questão da "língua". Isso porque a língua está intimamente ligada ao problema da Alsace-Lorraine: o falar dessa região é majoritariamente germânico (o principal argumento dos alemães), mas os franceses evitam, estrategicamente, tocar nesse assunto.

O essencial das idéias de Renan sobre a nação está no final de sua conferência que assim se inicia: "A nação é uma alma, um princípio espiritual [...] o desejo de viver juntos [...] uma grande solidariedade constituida pelo sentimento dos sacrificios [...] o desejo claramente expresso de continuar a vida em comum [...] um plebiscito diário...". A partir dessa definição, um tanto quanto lírica, é preciso recuperar o não-dito. Primeiramente não se sabe com exatidão o que é nação. Renan diz que é um plebiscito, mas em qual contexto? Em qual quadro territorial? Fala-se de nação como se ela existisse por si mesma. Mas, e se a posse de uma parcela de seu território onde vive uma parte dos homens e mulheres que a constituem é contestada por uma outra nação? E o que fazer se um outro Estado invade esse território? Faz-se um referendum? E se se recusa esse procedimento? Renan tem sempre em mente a questão da Alsace-Lorraine, que estava em voga na época. Ele toca, de forma bastante sutil, nessa questão: "Se existem dividas sobre [as] fronteiras, consultem as 
populações envolvidas. Elas têm o direito de ter uma opinião sobre o assunto. Eis o que fará sorrir os transcendentes da política..."

$\mathrm{Na}$ época, alguns se chocaram e até mesmo se indignaram com a extrema discrição com que Renan tratou da questão da AlsaceLorraine; viu-se aí o reflexo das relações muito cordiais que Renan mantinha com os filósofos alemães. Ele deveria ter abordado a questão lingüística que não era muito favorável à França, e poderia, também, ter levantado a participação muito ativa dos alsacienslorrains nas guerras da Revolução, o que era uma marca de nacionalismo francês, ou seja, de pertencimento à nação francesa. Mas Renan não diz nada e se resguarda. Ele era, com certeza, muito mais bem informado do que faz supor o angelismo do seu discurso.

Os prefácios e comentários que acompanham, hoje, as reedições do texto de Renan se restringem à famosa conferência, deixando de lado o contexto político-social em que ela foi proferida. Mesmo assim, as idéias expostas por Renan em sua conferência podem ser consideradas hoje como o rascunho de uma concepção totalmente democrática de nação: ele fala não somente de plebiscito entre as nações para decidir sobre as fronteiras litigiosas, mas sobretudo, no sentido mesmo de cada nação, de um "plebiscito diário". Nada de língua nem de território! Não é de se estranhar que os homens de esquerda de hoje evoquem com emoção esses princípios geopolíticos.

Pode-se, entretanto, perguntar como regulamentar as diferenças com os Estados que recusam tais plebiscitos. E o que devem fazer aqueles que recusam os resultados de um referendum que os tornou membros de tal nação? Eles devem partir? Renan não estaria mais uma vez caindo no angelismo? Poderíamos dizer que as idéias de Renan são utópicas, no seu sentido primeiro de $u$-topia, ou seja, sem lugar.

Essa questão de nação colocada por Renan há mais de um século em termos utópicos toma, hoje, significações políticas e geopolíticas muito mais concretas, não só em termos individuais, como por exemplo 
para os imigrados e seus descendentes, mas também do ponto de vista coletivo, para um grande número de pessoas que, como seus ancestrais, nasceram na França, mas que aspiram a uma outra nacionalidade corsa, bretã, basca, etc.

As idéias de Renan suscitam, hoje, um interesse novo e, a primeira vista, paradoxal, visto que, depois de servirem à França por mais de um século, essas idéias são evocadas para rediscutir, aparentemente da maneira mais democrática possível, a unidade nacional. Renan, tendo proclamado que a nação é "uma alma, um principio espiritual [...] a posse em comum de um rico legado de lembranças [...], a vontade de continuar a fazer valer a herança que se recebeu igualitariamente" fez que certos meios intelectuais estimassem que o Estado Francês - Reino ou República - estabelecesse pela força sua dominação sobre diversas nações até então independentes e culturalmente evoluidas. Dizem alguns corsos, bretões, catalães que, já que a França se quer um Estado Democrático e até mesmo um Estado de Direito, ela deve reconhecer a existência de seus diferentes povos e admitir que cada um é uma minoria regional dependente de uma maioria nacional. Esses povos - e porque não nações — pretendem estar prontos para defenderem, desenvolverem e fazerem valer seus próprios recursos e suas heranças específicas. Citando Renan, "consultem as populações envolvidas. Elas têm o direito de ter uma opinião sobre o assunto." As reivindicações identitárias não são somente culturais, são uma questão de democracia e de geopolítica.

Assim, no contexto da globalização, a modernização da idéia de nação é uma tarefa ainda necessária para salvaguardar as condições de desenvolvimento econômico e cultural. É por causa da globalização e do liberalismo econômico que o papel da nação, longe de declinar, toma uma nova dimensão. A nação será a última forma de organização política? Impossível responder a essa questão. É evidente que as nações nasceram e vão morrer um dia como muitas outras coisas. Mas, uma coisa é certa: hoje não somos capazes de viver sem ela. Assim, não devemos nos preocupar com o fim das nações, mas com o seu estado atual. 


\section{O que é uman nação?}

Ernest Renan.

Conferência feita na Sorbonne em 11 de março de 1882.

Proponho-me a analisar, juntamente com vocês, uma idéia, aparentemente clara, mas que se presta aos mais perigosos mal-entendidos. As formas da sociedade humana são muito variadas. Há grandes aglomerações de homens, tais como as da China, do Egito e da mais antiga Babilônia. Há, também, tribos, tais como as dos hebreus e dos árabes. Na sociedade humana, encontra-se cidades à maneira de Atenas e Esparta. Existem, ainda, reuniões de vários países, como é o caso do Império Carolíngeo. Encontramos entre os homens comunidades sem pátria, mantidas pelo elo religioso. Assim se caracterizam os israelitas e os parses. Destacam-se por um lado nações como a França, a Inglaterra e a maior parte das modernas autonomias européias e, por outro lado, confederações tais como a Suíça e a América. Não se podem esquecer os laços como os que a raça, ou melhor a língua estabelece entre os diferentes ramos de alemães e eslavos. Vejam os modos de agrupamentos que existem, ou existiram, e que não se confundiriam uns com os outros, sem que isso acarretasse os mais sérios problemas. Na época da Revolução Francesa, acreditava-se que as instituições de pequenas cidades independentes, tais como Esparta e Roma, podiam ser aplicadas às nossas grandes nações de trinta a quarenta milhões de almas. Hoje, comete-se um erro mais grave: confunde-se raça com nação, e se atribui a grupos etnográficos, ou melhor lingüísticos, uma soberania análoga àquela dos povos realmente existentes. Tentemos chegar a alguma precisão com referência a essas questões difíceis, em que a menor confusão sobre o sentido das palavras, na origem do raciocínio, pode produzir no final os mais funestos erros. O que vamos fazer é delicado: é quase um dissecamento vamos tratar dos vivos como se costuma tratar dos mortos. Trabalharemos com frieza e imparcialidade absoluta. 
Depois do fim do Império Romano, melhor dizendo, depois do deslocamento do Império de Carlos Magno, a Europa ocidental nos parece dividida em nações, entre as quais algumas, em certas épocas, procuraram exercer, sem jamais conseguir, de forma durável, uma hegemonia sobre as outras. O que Charles-Quint, Louis XIV e Napoléon I não conseguiram, provavelmente ninguém conseguirá no futuro. O estabelecimento de um novo Império Romano ou de um novo Império de Carlos Magno tornou-se uma impossibilidade. A divisão da Europa é grande demais para que uma tentativa de dominação universal não provoque muito rapidamente uma aliança entre as partes ameaçadas, o que fará recuar aos limites naturaìs a nação ambiciosa. Um tipo de equilíbrio é estabelecido por muito tempo. França, Inglaterra, Alemanha, Rússia serão, ainda por centenas de anos, e apesar das aventuras que elas terão vivido, individualidades históricas, peças essenciais de um jogo de dama, cujas casas variam incessantemente de importância e de grandeza, mas sem jamais se confundirem.

As nações, entendidas dessa forma, são alguma coisa de muito recente na história. A antiguidade não as conheceu; Egito, China e a antiga Babilônia não viveram nenhum grau desse tipo de nação. Eram grupos controlados por um filho do Sol ou um filho do Céu. Não houve cidadãos egípcios nem chineses. A antigüidade clássica teve repúblicas, realezas municipais, confederações de repúblicas locais e impérios, mas não se constituiu como nação no sentido em que a compreendemos. Atenas, Esparta, Sidon e Tiro foram pequenos centros de admirável patriotismo; entretanto, são cidades com um território relativamente restrito. Gália, Espanha, Itália, antes da absorção no Império Romano, eram conjuntos de povoados, freqüentemente ligados entre si, mas sem instituições centrais, sem dinastias. O Império Assírio, o Persa, o Império de Alexandre também não se constituiram como pátrias. Nunca houve patriotas assírios; o Império Persa foi um vasto feudalismo. Nenhuma nação liga suas origens à 
colossal aventura de Alexandre, que foi, entretanto, tão rica em conseqüências para a história geral da civilização.

O Império Romano esteve muito mais perto de ser uma pátria. Em troca das vantagens do fim das guerras, a dominação romana, que no princípio fọ tão dura, foi rapidamente vista com simpatia. Fez-se uma grande união, sinônimo de ordem, de paz e de civilização. Nos últimos tempos do Império, houve, entre as almas elevadas, os bispos esclarecidos e os letrados, um verdadeiro sentimento de "paz romana", em oposição ao caos ameaçador da barbárie. Mas um império doze vezes maior que a França atual não saberia formar um Estado na concepção moderna. A cisão do Oriente e do Ocidente era inevitável. As tentativas de um Império Gaulês, no Século III, não foram bem sucedidas. Foi a invasão germânica quem introduziu no mundo o princípio que mais tarde serviu de base para a existência das nacionalidades.

O que fizeram realmente os povos germânicos depois de suas grandes invasões, do Século $\mathrm{V}$ até as últimas conquistas normandas no Século X? Eles pouco influenciaram a realidade das raças, mas impuseram, em partes mais ou menos consideráveis do antigo Império do Ocidente, dinastias e uma aristocracia militar as quais tomaram o nome de seus invasores. Daí uma França, uma Burgondie, uma Lombardia; mais tarde uma Normandia. A supremacia do Império Franco fez que a unidade do Ocidente fosse retomada rapidamente, mas esse império se desfez de forma irremediável aproximadamente na metade do Século IX. O Tratado de Verdum determinou divisões, imutáveis a princípio, e desde então França, Alemanha, Inglaterra, Itália e Espanha encaminharam-se, por vias freqüentemente indiretas e através de mil aventuras, para a plena existência nacional, tal como a vemos desabrochar-se hoje.

O que caracteriza, de fato, estes diferentes Estados? A fusão das populações que os compõem. Nos países que acabamos de enumerar, nada de análogo ao que se encontra na Turquia, onde o turco, o eslavo, o grego, o armênio, o árabe, o sírio, o curdo são tão distintos hoje 
quanto na época da conquista. Duas circunstâncias essenciais contribuíram para esse resultado. Primeiramente, o fato de que os povos germânicos adotaram o cristianismo a partir do momento em que fizeram contatos freqüentes com os povos gregos e latinos. Quando o vencedor e o vencido têm a mesma religião, ou melhor, quando o vencedor adota a religião do vencido, como é o caso do sistema turco, a distinção absoluta dos homens segundo a religião não é mais possível. A segunda circunstância foi, por parte dos conquistadores, o esquecimento da própria língua. Os netos de Clovis, de Alaric, de Gondebaus, de Alboïn, de Rollon, já falavam romano. Este fato era em si mesmo a consequiência de uma outra particularidade importante: entre francos, burgondes, góticos, lombardos e normandos, havia poucas mulheres de suas próprias raças. Durante várias gerações os chefes só se casavam com mulheres germânicas. Entretanto, suas concubinas e as amas de seus filhos eram latinas. Toda a tribo esposava mulheres latinas, o que fez que a lingua francica e lingua gothica desaparecessem depois do estabelecimento dos francos e dos góticos em terras romanas. Mas isso não aconteceu na Inglaterra, porque a invasão anglo-saxônica contava, sem dúvida, com mulheres da própria raça. A população bretã fugiu e, além disso, o latim não era mais, ou até mesmo nunca foi, dominante na Bretanha. Se se tivesse falado gaulês na Gália, no Século V, Clovis e o seu povo não teriam trocado o germânico pelo gaulês.

Daí esse resultado capital: apesar da extrema violência dos costumes dos invasores germânicos, o modelo que eles impuseram tornou-se com os séculos, o próprio modelo da nação. França tornouse legitimamente o nome de um país onde havia somente uma imperceptível minoria de francos. No Século X, nas primeiras canções de gesta - um espelho tão perfeito do espírito daquele tempo - todos os habitantes da França eram franceses. A idéia de uma diferença de raças na população da França, tão evidente em Grégoire de Tours, não existiu em nenhum grau entre os escritores e poetas franceses posteriores a Hugues Capet. A diferença entre o nobre e o vilão era a 
mais acentuada possível. A diferença, entretanto, entre um e outro não tinha nada de étnico: era uma diferença de coragem, de hábitos e de educação transmitida hereditariamente. A idéia de que a origem de tudo isso fosse uma conquista não ocorria a ninguém: $O$ falso sistema segundo o qual a nobreza devia sua origem a um privilégio conferido pelo rei por grandes serviços prestados à nação, de tal modo que todo nobre era um enobrecido, se estabeleceu como um dogma desde o Século XIII. A mesma coisa aconteceu depois de quase todas as conquistas normandas. No final de uma ou duas gerações, os invasores normandos não se distinguiam mais do resto da população. Nem por isso, sua influência fora menos profunda. Eles haviam dado ao país conquistado uma nobreza, hábitos militares e um patriotismo que não existia antes.

O esquecimento, e até mesmo o erro histórico, são fatores essenciais na criação de uma nação. E é por isso que o progresso dos estudos históricos é, freqüentemente, um perigo para a nacionalidade. A investigação histórica, de fato, esclarece os fatos de violência que aconteceram na origem de todas as formações políticas, até mesmo daquelas cujas as consequiências foram as mais salutares. A unidade se faz sempre de forma brutal. A união entre a França do Norte e a do Midi foi o resultado de uma exterminação e um terror contínuo durante quase um século. O rei da França - o tipo ideal de um cristalisador centenário, aquele que promoveu a mais perfeita unidade nacional - visto de perto, perdeu seu prestígio. A nação que ele havia formado o amaldiçoou, e, hoje, somente os espíritos cultos sabem o que ele valia e o que ele fez.

É pelo contraste que essas grandes leis da história da Europa ocidental tornam-se sensíveis. A empreitada que o rei da França, em parte pela sua tirania, em parte pela sua justiça, levou tão admiravelmente a termo, não foi conseguida por muitos países. Sob a coroa de Saint Étienne, húngaros e eslavos permaneceram tão distintos quanto eram oitocentos anos antes. Longe de fundir os elementos diversos de seus domínios, a Casa de Habsbourg os manteve separados e freqüentemente opostos uns aos outros. Na Boêmia, o elemento tcheco 
e o elemento alemão ficaram superpostos como o óleo e a água. A política turca da separação das nacionalidades segundo a religião teve consequiências muito mais graves: ela causou a ruína do oriente. Tome como exemplo uma cidade como Salonique ou Smyrne e vocês encontrarão cinco ou seis comunidades, cada uma com suas próprias lembranças e tendo quase nada em comum entre si. Ora, a essência de uma nação é que todos os indivíduos tenham muitas coisas em comum, e também que todos tenham esquecido muitas coisas. Nenhum cidadão francês sabe se ele é burgonde, alain, taïfale, visigoth. Todo cidadão francês deve ter esquecido a episódio de Saint-Barthélemy, os massacres do Midi no Século XIII. Não há na França dez famílias que possam fornecer a prova de uma orígem franca, e se existisse tal prova, ela seria essencialmente defeituosa, devido a seqüência de mil cruzamentos desconhecidos que podem atrapalhar todos os sistemas dos genealogistas.

A nação moderna é, assim, um resultado histórico ocasionado por uma série de fatos que convergem em um mesmo sentido. Essa unidade pôde ser realizada por diversos caminhos ou formas: por uma dinastia, como foi o caso da França; pela vontade direta das províncias, como é o caso da Holanda, Suíça e Bélgica; por um espírito geral, tardiamente vencedor dos caprichos do feudalismo, como é o caso da Itália e Alemanha. Sempre uma profunda razão de ser presidiu essas formações. Os princípios, nesses casos, surgem de maneiras totalmente inesperadas. Nós vemos, hoje em dia, a Itália unificada por suas derrotas e a Turquia demolida por suas vitórias. Cada derrota fazia avançar as coisas da Itália; cada vitória arruinava a Turquia. Isso porque a Itália é uma nação, e a Turquia, fora da Ásia Menor, não o é. A glória da França é a de ter, pela Revolução Francesa, proclamado que uma nação existe por si mesma. Não devemos achar ruim quando nos imitam. O princípio das nações é o nosso. Mas, o que é, então, uma nação? Por que a Holanda é uma nação, enquanto Hanover ou o Grão-Ducado de Parma não o são? Como a França persiste como nação, quando o princípio que a criou desapareceu? Como a Suíça, que tem três línguas, duas religiões, três ou quatro 
raças, é uma nação, enquanto que a Toscana, por exemplo, que é tão homogênea, não é considerada uma nação? Por que a Áustria é um Estado mas não é uma nação? Em que o princípio das nacionalidades difere do princípio das raças? Eis alguns pontos a respeito dos quais um espírito prudente insiste em se certificar, para estar em concordância consigo mesmo. As coisas do mundo não se regulam mais por esses tipos de raciocínios. Entretanto, os homens sensatos querem trazer a essas matérias alguma racionalização e esclarecer as confusões em que os espíritos superficiais se perdem.

\section{III}

Segundo alguns teóricos políticos, uma nação é antes de tudo uma dinastia, a qual representa uma antiga conquista que, no princípio, foi aceita, mas, depois, esquecida pelo povo. Segundo as políticas das quais eu estou falando, o agrupamento de províncias efetuado por uma dinastia, através de suas guerras, casamentos e tratados, acaba com a dinastia que a formou. É verdade que a maior parte das nações modernas foram feitas por uma família de origem feudal, que se ligou à terra pelo matrimônio e que foi de certa forma um núcleo de centralização. As fronteiras da França em 1789 não tinham nada de natural nem de necessário. A larga faixa que a Casa Capetiana havia agregado ao estreito limite do Tratado de Verdum foi a aquisição pessoal dessa casa. Na época em que foram feitas as anexações, não se pensava nem em limites naturais, nem em direito das nações e nem tampouco na vontade das províncias. A união da Inglaterra, da Irlanda e da Escócia foi também um fenômeno dinástico. A Itália só demorou muito para ser uma nação porque nenhuma de suas numerosas casas reinantes tornou-se, antes do nosso século, o centro da unidade. Estranho é que foi da obscura ilha de Sardenha, nem ainda italiana, que ela adquiriu um título real. A Holanda, que se constituiu sozinha, por um ato de heróica resolução, se ligou intimamente, entretanto, à Casa de Orange, e ela correria sérios riscos se essa união fosse comprometida. 
Esse tipo de lei pode, entretanto, ser absoluta? Sem dúvida que não. A Suíça e os Estados Unidos, que se formaram como conglomerados de adições sucessivas, não têm nenhuma base dinástica. Eu não discutirei a questão concernante à França. Seria preciso ter o segredo do futuro. Digamos somente que essa grande realeza francesa havia sido tão altamente nacional que, no dia seguinte à sua queda, a nação pôde se sustentar sem ela. E, além disso, o Século XVIII mudara muita coisa. O homem havia voltado, depois de séculos de humilhação, ao espírito antigo, ao respeito por si mesmo, à idéia de seus direitos. As palavras pátria e cidadão haviam retomado seus sentidos. Assim, pôde-se realizar a operação mais audaciosa já praticada na história. Operação que pode ser comparada àquilo que seria, em fisiologia, a tentativa de fazer viver em sua identidade primeira um corpo do qual teria sido retirado o cérebro e o coração.

É necessário, então, admitir que uma nação pode existir sem princípio dinástico, e até aquelas que foram formadas por dinastias podem se separar dessas, sem, por isso, deixarem de existir. $O$ velho princípio que só leva em conta o direito dos príncipes não poderia mais ser mantido. Além do direito dinástico, há o direito nacional. Sobre que critérios pode-se fundar esse direito nacional? Por que indício conhecê-lo? De qual fato tangível fazê-lo derivar?

\section{I - Muitos dizem, com segurança, que é da raça.}

As divisões artificiais, resultantes do feudalismo, dos casamentos principescos, dos congressos de diplomatas, são caducas. O que permanece firme e fixo é a raça das populações. Eis o que constitui um direito, uma legitimidade. A família germânica, por exemplo, segundo a teoria que exponho, tem o direito de retomar os membros esparsos do germanismo, mesmo quando esses membros não pedem para ser reunidos. O direito do germanismo sobre tal província é mais forte que o direito dos habitantes dessa província sobre eles mesmos. Cria-se, assim, um tipo de direito primordial análogo àquele dos reis de direito divino; ao princípio das nações substitui-se aquele da 
etnografia. Isso é um grande erro, que se se tornasse dominante, poderia destruir a civilização européia. Do mesmo modo que o princípio das nações é justo e legítimo, o princípio do direito primordial das raças é estreito e cheio de perigos para o verdadeiro progresso.

Nas tribos e nas cidades antigas, a questão da raça tinha, como se sabe, uma importância primordial. As tribos e as cidades antigas não eram senão uma extensão da família. Em Esparta e Atenas todos os cidadãos eram parentes em graus mais ou menos próximos. A mesma coisa acontecia com os Beni-Israël. E continua assim nas tribos árabes. De Atenas, Esparta e da tribo israelita, transportemo-nos até o Império Romano. A situação é completamente diferente. Formada, a princípio, pela violência, e depois mantida pelo interesse, essa grande aglomeração de cidades, de províncias absolutamente diferentes, feriu gravemente a idéia de raça. O cristianismo, com seu caráter universal e absoluto, trabalhou mais eficazmente ainda no mesmo sentido. Ele fez uma aliança íntima com o Império Romano e, pelo efeito desses dois incomparáveis agentes de unificação, a razão etnográfica é afastada do governo das coisas humanas por muitos séculos.

A invasão dos bárbaros foi, apesar das aparências, um passo a mais nesse caminho. As divisões de reinos bárbaros não têm nada de etnográfico. Elas são reguladas pela força ou pelo capricho dos invasores. A raça das populações que os bárbaros subordinavam era, para eles, totalmente indiferente. Carlos Magno refez à sua maneira o que Roma já havia feito: um império único composto das mais diversas raças. Os autores do Tratado de Verdum, traçando imperturbavelmente suas duas grandes linhas do norte ao sul, não tiveram a menor preocupação com a raça das pessoas que se encontravam à direita ou à esquerda. Os movimentos de fronteira que se operaram logo depois, no decorrer da Idade Média, estiveram também fora de qualquer tendência etnográfica. Se a política contínua da Casa Capetiana chegou a agrupar mais ou menos, sob o nome de França, os territórios da antiga Gália, não foi em razão da tendência que teriam tido esses países a se ajuntar aos seus congêneres. Dauphiné, Bresse, Provence, Franche-Comté não se lembravam mais de uma origem comum. Toda 
consciência gaulesa havia desaparecido desde o Século II de nossa era, e, hoje, somente através da erudição pôde-se encontrar retrospectivamente a individualidade do caráter gaulês.

A consideração etnográfica não teve nenhum papel na constituição das nações modernas. A França é céltica, ibérica e germânica. A Alemanha é germânica, céltica e eslava. A Itália é o país onde a etnografia é a mais confusa. Gauleses, etruscos, pélasgos, gregos, sem falar de muitos outros elementos, ai se cruzam em uma indecifrável mistura. As ilhas britânicas, no seu conjunto, são uma mistura de sangue céltico e germânico cujas proporções são singularmente difíceis de definir.

A verdade é que não há raça pura e que basear a política na análise etnográfica é colocá-la sobre uma quimera. Os países mais nobres como Inglaterra, França e Itália, são aqueles onde o sangue é o mais misturado. A Alemanha é uma exceção? Ela é um país germânico puro? Que ilusão! Todo o sul foi gaulês. Todo o leste, a partir de Elba, é eslavo. E as partes que se pretendem realmente puras, o são realmente? Tocamos aqui em um dos problemas sobre os quais o mais importante é construir idéias claras e prevenir os mal-entendidos.

As discussões sobre as raças são intermináveis porque a palavra raça é tomada pelos historiadores-filólogos e pelos antropólogosfisiologistas em dois sentidos completamente diferentes. Para os antropólogos, a raça tem o mesmo sentido que em zoologia: ela indica uma descendência real, um parentesco pelo sangue. Ora, o estudo das línguas e da história não conduz às mesmas divisões que a fisiologia. As palavras dos braquicéfalos, de dolicocéfalos não têm lugar nem na história nem na filologia. No grupo humano que criou as línguas e a disciplina arianas, já havia braquicéfalos e dolicocéfalos. É preciso dizer a mesma coisa para o grupo primitivo que criou as línguas e a instituição ditas semíticas. Em outros termos, as orígens zoológicas da humanidade são muito anteriores às origens da cultura, da civilização e da linguagem. Os grupos ariano primitivo, semítico primitivo, turaniano primitivo não tinham nenhuma unidade fisiológica. 
Esses agrupamentos são fatos históricos que aconteceram em uma certa época, aproximadamente há quinze ou vinte mil anos, enquanto que a origem zoológica da humanidade se perde nas obscuridades incalculáveis. Aquilo a que chamamos filológica-historicamente de raça germânica é seguramente uma família bem distinta na espécie humana. Mas será uma família no sentido antropológico? Decerto que não. A aparição da individualidade germânica na história se fez somente alguns séculos antes de Jesus Cristo. Aparentemente os germânicos não brotaram do chão nessa época. Antes disso, misturados aos eslavos na grande massa indistinta dos scythes, eles não possuiam sua individualidade à parte. Um inglês é de fato um tipo no conjunto da humanidade. Ora, o tipo daquilo a que chamamos muito impropriamente de raça anglo-saxônica não é nem o bretão do tempo de César, nem o anglo-saxão de Hengist, nem o dinamarquês de Knut, nem o normando de Guillaume, o Conquistador. É a soma de tudo isso. $O$ francês não é nem um gaulês, nem um franco, nem um burgonde. Ele é o que saiu dessa grande caldeira onde, sob a presidência do rei da França, fermentaram juntos elementos os mais diversos. Um habitante de Jersey ou de Guernesey não diferem em nada, pelas origens, da população normanda da costa vizinha. No século $\mathrm{XI}$, o olho mais aguçado não teria conseguido perceber nas duas margens do canal a menor diferença. Circunstâncias insignificantes fizeram que Philippe-Auguste não tomasse as ilhas com o resto da Normandia. Separadas uma da outra há aproximadamente setecentos anos, as duas populações se tornaram não somente estrangeiras uma para a outra, mas completamente diferentes. A raça, tal como a entendemos nós, historiadores, é, assim, algo que se faz e se desfaz. $O$ estudo da raça é importante para o estudioso que se ocupa da história da humanidade. Ele não tem aplicação no campo da política. A consciência instintiva que dominou no momento da confecção do mapa da Europa não levou em conta a raça, e as primeiras nações da Europa são nações de sangue essencialmente misturado.

Assim, a questão da raça, importante na origem, vai perdendo sua importância. A história humana difere essencialmente da zoologia. 
A raça não é tudo, como o é para os roedores ou os felinos, e não temos o direito de sair pelo mundo apalpando o crânio das pessoas e depois pegá-las pelo pescoço e dizer-lhes: "você é nosso sangue; você pertence a nós! "Fora das características antropológicas, há a razão, a justiça, a verdade, o belo, que são os mesmos para todos. Veja como essa política etnográfica não é segura. Os homens a exploram hoje uns contra os outros e depois a vêem se virar contra si mesmos. Será que os alemães, que levantaram tão alto a bandeira da etnografia, não verão os eslavos analisar, por sua vez, os nomes das cidades da Saxe e da Lusace, procurar os traços dos wiltzes ou dos obotrites, e pedir contas dos massacres e das vendas em massa que othons fizeram de seus ancestrais? Por todos é bom saber esquecer.

Gosto muito da etnografia. É uma ciência de um raro interesse. Mas, como a quero livre, quero-a sem aplicação política. Em etnografia, como em todos os estudos, os sistemas mudam. É a condição do progresso. Os limites dos Estados seguiriam as flutuações da ciência. O patriotismo dependeria de uma dissertação mais ou menos paradoxal. Viríamos dizer ao patriota: "Você se enganou, você derramou seu sangue por tal causa. Você acreditava ser celta. Não, você é germano". Dez anos depois viríamos dizer-lhe que você é eslavo. Para não falsificar a ciência, dispensêmo-la de dar uma opinião sobre esses problemas, em que tantos interesses estão em jogo. Estejam certos de que, se a encarregamos de fornecer elementos para a diplomacia, nós a surpreenderemos muitas vezes em flagrante delito de complacência. Ela tem coisa melhor para fazer: peçamos-lhe simplesmente a verdade.

\section{III - O que acabamos de dizer sobre a raça, precisamos dizer sobre a língua.}

A língua é um convite à união, não um mandamento. Os Estados Unidos e a Inglaterra, a América Espanhola e a Espanha falam a mesma língua e não formam uma só nação. Por outro lado, a Suíça, tão bem feita, já que ela foi feita pelo acordo de suas diferentes partes, 
conta com três ou quatro línguas. Há no homem alguma coisa de superior à língua: a vontade. A vontade da Suíça de ser unida, apesar da variedade de seus idiomas, é um fato muito mais importante que uma semelhança quase sempre obtida pelos vexames.

Um fato honorável para a França é o de que ela jamais procurou obter a unidade da língua por medidas de coerção. Não se pode ter os mesmos sentimentos e os mesmos pensamentos, amar as mesmas coisas em línguas diferentes? Falávamos há pouco sobre o inconveniente que seria ter a política internacional dependendo da etnografia. Teríamos o mesmo inconveniente se a tivéssemos na dependência da filologia comparada. Deixemos para esses interessantes estudos a inteira liberdade de suas discussões. Não os misturemos àquilo que alteraria a sua serenidade. A importância política que se dá às línguas vem do fato de se ver nelas sinais de raça. Nada mais falso. A Prússia, onde se fala somente o alemão, falava eslavo há alguns séculos. $O$ País de Gales fala inglês. A Gália e a Espanha falam o idioma primitivo de Alba la Longue. O Egito fala árabe. Os exemplos são inúmeros. Mesmo nas origens, a semelhança de língua não levava à semelhança de raça. Tomemos como modelo a tribo proto-ariana ou proto-semita. Havia alí escravos que falavam a mesma língua de seus mestres. Ora, freqüentemente, o escravo era de uma raça diferente daquela de seu mestre. Repetindo: essas divisões de línguas indo-européias, semíticas e outras, criadas com uma tão admirável sagacidade pela filologia comparada, não coincidem com as divisões da antropologia. As línguas são formações históricas, que indicam poucas coisas sobre $o$ sangue daqueles que as falam. Em todo caso, elas não poderiam acorrentar a liberdade humana quando se trata de determinar a família com a qual alguém se une até a morte.

Essa consideração exclusiva da língua tem, assim como a atenção muito forte dada à raça, seus perigos, seus inconvenientes. Quando alguém exagera, fecha-se em uma cultura determinada, tida como nacional. Limita-se, enclausura-se. Deixa-se de respirar o ar no vasto campo da humanidade para fechar-se nos conventículos de compatriotas. Não há nada pior para o espírito. Nada mais deplorável para a 
civilização. Não abandonemos esse princípio fundamental de que o homem é um ser racional e moral, antes de ser amarrado a tal ou tal língua, antes de ser um membro de tal ou tal raça, pertencente a tal ou tal cultura. Antes da cultura francesa, alemã, italiana, há a cultura humana. Vejam os grandes homens da Renascença. Eles não eram nem franceses, nem italianos, nem alemães. Eles tinham encontrado, pelo comércio com a antigüidade, o segredo da verdadeira educação do espírito humano, e eles se dedicaram a isso de corpo e alma. Como eles fizeram bem!

\section{IIII - A religião também não poderia oferecer uma base suficiente} para o estabelecimento de uma nacionalidade moderna.

$\mathrm{Na}$ origem, a religião era ligada à existência do grupo social. Esse era uma extensão da família. A religião, os ritos, eram ritos de família. A religião de Atenas, era o próprio culto de Atenas, de seus fundadores míticos, de suas leis, de seus usos. Ela não implicava nenhuma teologia dogmática. Essa religião era, com toda a força do termo, uma religião de Estado. Não se era ateniano se se recusava praticar a religião de Atenas. A religião era, no fundo, o culto da Acrópole personificada. Jurar sobre o autar de Aglaure, era prestar juramento de morrer pela pátria. Essa religião era o equivalente daquilo que para nós significa sortear, ou o culto à bandeira. Recusar-se a participar de um tal culto era como se fosse, em nossas sociedades modernas, recusar-se a prestar o serviço militar. Era o mesmo que declarar que não se era ateniense. Por outro lado, é claro que tal culto não tinha sentido para aquele que não era de Atenas. Por isso não se utilizava de nenhum proselitismo para forçar os estrangeiros a aceitarem esse culto. Os escravos de Atenas não o praticavam. A mesma coisa acontecia em algumas pequenas repúblicas da Idade Média. Não se era um bom vénitien se não se acreditasse em São Marco. Não se era um bom amalfitain se não se colocasse Santo André acima de todos os outros santos do paraíso. Nessas pequenas 
sociedades, o que virou mais tarde perseguição, tirania, era legítimo e não tinha nada de grave como se fosse, para nós, parabenizar um pai de família no dia de sua festa e lhe desejar felicidade na passagem de ano.

O que era verdade em Esparta, em Atenas, não o era mais para os reinos saídos da conquista de Alexandre, não o era mais sobretudo no Império Romano. As perseguições de Antiochus Épiphane para levar o Oriente ao culto de Júpiter Olimpiano, aquelas do Império Romano para manter uma pretensa religião de Estado foram um erro, um crime, um verdadeiro absurdo. Hoje, a situação é perfeitamente clara. Não há mais massas com uma única crença. Cada um crê e pratica o que quer, como quer e se quiser. Não há mais religião de Estado. Pode-se ser francês, inglês, alemão, sendo católico, protestante, israelita, sem praticar nenhum culto. A religião tornou-se coisa individual. Ela depende da consciência de cada um. A divisão das nações em católicas, protestantes, não existe mais. A religião, que, há cinquenta e dois anos, era um elemento tão considerável na formação da Bélgica, guarda toda a sua importância no foro íntimo de cada um. Mas, ela saiu quase inteiramente das razões que traçam os limites dos povos.

\section{IV - A comunidade dos interesses é seguramente um vínculo potente entre os homens.}

Os interesses, entretanto, são suficientes para fazer uma nação? Acho que não. A comunidade dos interesses faz os tratados de comércio. Há na nacionalidde um lado sentimental. Ela é alma e corpo ao mesmo tempo. Um Zollverein não é uma pátria.

\section{V - A geografia, aquilo que podemos chamar de fronteiras} naturais, tem, certamente, uma parte considerável na divisão das nações.

A geografia é um dos fatores essenciais da história. Os rios conduziram as raças. As montanhas as retiveram. Os primeiros favorece- 
ram, as segundas limitaram os movimentos históricos. Será possível dizer, entretanto, como acreditam alguns partidos, que os limites de uma nação são escritos no mapa e que essa nação tem o direito de outorgar-se o que lhe é necessário para arredondar certos contornos, para alcançar tal montanha, tal rio, a que se atribui uma espécie de faculdade limitativa a priori? Não conheço doutrina mais arbitrária nem mais funesta. Com isso, justifica-se todas as violências. E, primeiramente: são as montanhas ou são os rios que formam essas pretensas fronteiras naturais? É incontestável que as montanhas separam. Mas, os rios, ao contrário, reúnem. E, além disso, todas as montanhas não poderiam separar Estados. Quais são aquelas que separam e aquelas que não separam? De Biarritz a Tornea, ñão há uma foz de rio que tenha mais que outra uma característica de limite. Se a história humana tivesse querido, o Loire, o Sena, o Meusa, o Elba, o Oder teriam, tanto quanto o Rhin, esse carárer de fronteira natural que fez cometer tantas infrações em nome do direito fundamental, que é a vontade dos homens. Fala-se de razões estratégicas. Nada é absoluto. É claro que várias concessões devem ser feitas na medida das necessidades. Mas não se podem levar essas concessões muito longe. Senão todo mundo vai reclamar suas conveniências militares, e isso representará uma guerra sem fim. Não, não é a terra, mais que a raça, que faz uma nação. A terra fornece o substrato, o campo da luta e do trabalho. O homem fornece a alma. O homem é tudo na formação dessa coisa sagrada que se chama povo. Nada de material é suficiente. Uma nação é um princípio espiritual, resultante das complicações profundas da história, uma família espiritual, não um grupo determinado pelo configuração do solo.

Acabamos de ver o que não é suficiente para criar um tal princípio espiritual: a raça, a língua, os interesses, a afinidade religiosa, a geografia, as necessidades militares. O que mais é preciso, então? Na seqüência do que foi dito anteriormente, não vou mais prender por muito mais tempo a atenção de vocês. 


\section{III}

Uma nação é uma alma, um princípio espiritual. Duas coisas que, para dizer a verdade, são uma só, constituem essa alma, esse princípio espiritual. Uma está no passado e a outra no presente. Uma é a posse em comum de um rico legado de lembranças. A outra é o consentimento atual, o desejo de viver juntos, a vontade de continuar a fazer valer a herança que se recebeu indivisa. O homem, Senhores, não se improvisa. A nação, como o indivíduo, é o resultado de um longo passado de esforços, de sacrifícios e de devotamentos. $O$ culto aos ancestrais é entre todos o mais legítimo. Os ancestrais fizeram de nós o que somos. Um passado heróico, grandes homens, a glória (me refiro à verdadeira), eis o capital social sobre o qual se assenta uma idéia nacional. Ter glórias comuns no passado, uma vontade comum no presente, ter feito grandes coisas juntos, querer fazer mais, eis as condições essenciais para tornar-se um povo. Ama-se na proporção dos sacrifícios consentidos, dos males sofridos. Amamos a casa que construímos e que legamos. O canto espártaco: "Nós somos o que vocês foram, nós seremos o que vocês são" é, em sua simplicidade, o hino resumido de qualquer pátria.

No passado, uma herança de glória e de frustrações para partilhar, no futuro um mesmo programa a realizar. Ter sofrido, gozado, esperado juntos, eis o que vale mais que duanas comuns e fronteiras conforme as idéias estratégicas. Eis o que se entende, apesar das diversidades de raça e de língua. Eu dizia a pouco: "ter sofrido juntos". Sim, o sofrimento em comum une mais que a alegria. No tocante a lembranças nacionais, os lutos valem mais que os triunfos, pois eles impõem deveres, eles pedem o esforço comum.

Uma nação é, assim, uma grande solidariedade, constituída pelo sentimento de sacrifícios já feitos e daqueles que ainda estão por fazer. Ela supõe um passado. Ela se resume, entretanto, no presente por um fato tangível: o consentimento, o desejo claramente expresso de continuar a vida em comum. A existência de uma nação é (perdoem-me essa metáfora) um plebiscito diário, como a existência do 
indivíduo é uma afirmação perpétua da vida. Oh! Eu sei bem, isso é menos metafísico que o direito divino, menos brutal que o direito pretensamente histórico. Na ordem das idéias que submeto a vocês, uma nação não tem mais que um rei o direito de dizer à uma província: "Você me pertence, eu te tomo como minha". Uma província, para nós, são seus habitantes. Se alguém nesse negócio tem direito de ser consultado, esse alguém é o habitante. Uma nação nunca tem um verdadeiro interesse em anexar ou em reter um país contra a vontade deste. $O$ voto das nações é, definitivamente, o único critério legítimo, aquele ao qual é sempre necessário voltar.

Nós banimos da política as abstrações metafísicas e teológicas. O que fica depois disso? Fica o homem, seus desejos, suas,necessidades. A secessão, vocês me dirão, e, a dissipação das nações são a conseqüência de um sistema que coloca esses velhos organismos à mercê de vontades freqüentemente pouco esclarecidas. É claro que em matéria similar, nenhum princípio deve ser levado ao excesso. As verdades dessa ordem não são aplicáveis senão em seu conjunto e de maneira muito generalizada. As vontades humanas mudam. Mas, o que não muda? As nações não são algo eterno. Elas tiveram um início, elas terão um fim. A confederação européia, provavelmente, substituirá as atuais nações. Mas essa não é a lei do século em que vivemos. Hoje, a existência das nações é boa, até mesmo necessária. A sua existência é a garantia da liberdade, que estaria perdida se o mundo não tivesse senão uma lei e um mestre.

Por suas diversas faculdades, freqüentemente opostas, as nações servem à obra comum da civilização. Todas trazem uma nota para o grande concerto da humanidade, que, em suma, é a mais alta realidade ideal que podemos alcançar. Isoladas, elas têm suas partes frágeis. Eu digo freqüentemente que um indivíduo que tivesse os defeitos aceitos nas nações como qualidades, que se alimentasse de glória vã; que fosse ciumento, egoísta, brigão; que não pudesse suportar nada sem puxar a arma, seria o mais insuportável dos homens. Mas todas essas dissonâncias de detalhe desaparecem no conjunto. Pobre humanidade, como você sofreu! Por quantas provas você ainda terá de passar! 
Que o espírito da sabedoria possa guiá-la para preservá-la dos inúmeros perigos semeados em seu caminho!

Resumindo, senhores, o homem não é escravo nem de sua raça, nem de sua língua, nem de sua religião, nem do curso dos rịos, nem da direção das cadeias de montanhas. Uma grande agregação de homens, sã de espírito e quente de coração, cria uma consciência moral que se chama nação. Enquanto essa consciência moral provar sua força pelos sacrifícios que exige a abdicação do indivíduo em proveito de uma comunidade, ela é legítima, ela tem o direito de existir. Se existem dúvidas em relação a suas fronteiras, consultem as populações envolvidas. Elas têm o direito de ter uma opinião sobre o assunto. Eis o que fará sorrir os transcendentes da política, esses infalíveis que passam a vida a se enganar e que, do alto de seus princípios superiores, têm dó de nossa concepção terra-a-terra. "Consultar as populações é ingenuidade! Eis essas pobres idéias francesas que pretendem substituir a diplomacia e a guerra por meios de uma simplicidade infantil." - Esperemos, senhores. Deixemos passar c reino dos transcendentes. Saibamos suportar a arrogância dos fortes. Talvez, após várias tentativas infrutíferas, voltaremos às nossas modestas soluções empíricas. O meio de ter razão no futuro é, em certas horas, saber se resignar em ser fora de moda.

Résumé: traduction de la conférence $Q u$ 'est-ce qu'une nation? d'Ernest Renan prononcée le 11 mars dans le grand amphithéâtre de la Sorbonne, précédée d'une présentation critique.

\section{Bibliografia}

ERNEST, Renan. Qu'est.ce qu'une Nation? 1882. Saisie du texte: S. Pestel pour la collection électronique de la Bibliothèque Municipale de Lisieux (17.02.1997). 


\section{Qu'est-ce qu'une nation?}

ERNEST RENAN

Conférence faite en Sorbonne, le 11 mars 1882

Je me propose d'analyser avec vous une idée, claire en apparence, mais qui prête aux plus dangereux malentendus. Les formes de la société humaine sont des plus variées. Les grandes agglomérations d'hommes à la façon de la Chine, de l'Égypte, de la plus ancienne Babylonie; - la tribu à la façon des Hébreux, des Arabes; - la cité à la façon d'Athènes et de Sparte; - les réunions de pays divers à la manière de l'Empire carlovingien; - les communautés sans patrie, maintenues par le lien religieux, comme sont celles des israélites, des parsis; - les nations comme la France, l'Angleterre et la plupart des modernes autonomies européennes; - les confédérations à la façon de la Suisse, de l'Amérique; - des parentés comme celles que la race, ou plutôt la langue, établit entre les différentes branches de Germains, les différentes branches de Slaves; - voilà des modes de groupements qui tous existent, ou bien ont existé, et qu'on ne saurait confondre les uns avec les autres sans les plus sérieux inconvénients. À l'époque de la Révolution française, on croyait que les institutions de petites villes indépendantes, telles que Sparte et Rome, pouvaient s'appliquer à nos grandes nations de trente à quarante millions d'âmes. De nos jours, on commet une erreur plus grave: on confond la race avec la nation, et l'on attribue à des groupes ethnographiques ou plutôt linguistiques une souveraineté analogue à celle des peuples réellement existants. Tâchons d'arriver à quelque précision en ces questions difficiles, où la moindre confusion sur le sens des mots, à l'origine du raisonnement, peut produire à la fin les plus funestes erreurs. Ce que nous allons faire est délicat; c'est presque de la vivisection; nous allons traîter les vivants comme d'ordinaire on traite les morts. Nous y mettrons la froideur, l'impartialité la plus absolue. 
Depuis la fin de l'Empire romain, ou, mieux, depuis la dislocation de l'Empire de Charlemagne, l'Europe occidentale nous apparaît divisée en nations, dont quelques-unes, à certaines époques, ont cherché à exercer une hégémonie sur les autres, sans jamais y réussir d'une manière durable. Ce que n'ont pu Charles-Quint, Louis XIV, Napoléon Ier, personne probablement ne le pourra dans l'avenir. L'établissement d'un nouvel Empire romain ou d'un nouvel Empire de Charlemagne est devenu une impossibilité. La division de l'Europe est trop grande pour qu'une tentative de domination universelle ne provoque pas très vite une coalition qui fasse rentrer la nation ambitieuse dans ses bornes naturelles. Une sorte d'équilibre est établi pour longtemps. La France, l'Angleterre, l'Allemagne, la. Russie seront encore, dans des centaines d'années, et malgré les aventures qu'elles auront courues, des individualités historiques, les pièces essentielles d'un damier, dont les cases varient sans cesse d'importance et de grandeur, mais ne se confondent jamais tout à fait.

Les nations, entendues de cette manière, sont quelque chose d'assez nouveau dans l'histoire. L'antiquité ne les connut pas; l'Égypte, la Chine, l'antique Chaldée ne furent à aucun degré des nations. C'étaient des troupeaux menés par un fils du Soleil, ou un fils du Ciel. Il n'y eut pas de citoyens égyptiens, pas plus qu'il n'y a de citoyens chinois. L'antiquité classique eut des républiques et des royautés municipales, des confédérations de républiques locales, des empires; elle n'eut guère la nation au sens où nous la comprenons. Athènes, Sparte, Sidon, Tyr sont de petits centres d'admirable patriotisme; mais ce sont des cités avec un territoire relativement restreint. La Gaule, l'Espagne, l'Italie, avant leur absorption dans l'Empire romain, étaient des ensembles de peuplades, souvent liguées entre elles, mais sans institutions centrales, sans dynasties. L'Empire assyrien, l'Empire persan, l'Empire d'Alexandre ne furent pas non plus des patries. Il n'y eut jamais de patriotes assyriens ; l'Empire persan fut une vaste féodalité: Pas une nation ne rattache ses origines à la colossale aventure 
d'Alexandre, qui fut cependant si riche en conséquences pour I'histoire générale de la civilisation.

L'Empire romain fut bien plus près d'être une patrie. En retour de l'immense bienfait de la cessation des guerres, la domination romaine, d'abord si dure, fut bien vite aimée. Ce fut une grande association, synonyme d'ordre, de paix et de civilisation. Dans les derniers temps de l'Empire, il y eut, chez les âmes élevées, chez les évêques éclairés, chez les lettrés, un vrai sentiment de «la paix romaine», opposée au chaos menaçant de la barbarie. Mais un empire, douze fois grand comme la France actuelle, ne saurait former un État dans l'acception moderne. La scission de l'Orient et de l'Occident était inévitable. Les essais d'un empire gaulois, au IIIe, siècle, ne réussirent pas. C'est l'invasion germanique qui introduisit dans le monde le principe qui, plus tard, a servi de base à l'existence des nationalités.

Que firent les peuples germaniques, en effet, depuis leurs grandes invasions du Ve siècle jusqu'aux dernières conquêtes normandes au Xe? Ils changèrent peu le fond des races ; mais ils imposèrent des dynasties et une aristocratie militaire à des parties plus ou moins considérables de l'ancien Empire d'Occident, lesquelles prirent le nom de leurs envahisseurs. De là une France, une Burgondie, une Lombardie ; plus tard, une Normandie. La rapide prépondérance que prit l'empire franc refait un moment l'unité de l'Occident; mais cet empire se brise irrémédiablement vers le milieu du IXe siècle; le traité de Verdun trace des divisions immuables en principe, et dès lors la France, l' Allemagne, l'Angleterre, l'Italie, l'Espagne s'acheminent, par des voies souvent détournées et à travers mille aventures, à leur pleine existence nationale, telle que nous la voyons s'épanouir aujourd'hui.

Qu'est-ce qui caractérise, en effet, ces différents États? C'est la fusion des populations qui les composent: Dans les pays que nous venons d'énumérer, rien d'analogue à ce que vous trouverez en Turquie, où le Turc, le Slave, le Grec, l'Arménien, l'Arabe, le Syrien, le Kurde sont aussi distincts aujourd'hui qu'au jour de la conquête. 
Deux circonstances essentielles contribuèrent à ce résultat. D'abord le fait que les peuples germaniques adoptèrent le christianisme dès qu'ils eurent des contacts un peu suivis avec les peuples grecs et latins. Quand le vainqueur et le vaincu sont de la même religion, ouplutôt, quand le vainqueur adopte la religion du vaincu, le système turc, la distinction absolue des hommes d'après la religion, ne peut plus se produire. La seconde circonstance fut, de la part des conquérants, l'oubli de leur propre langue. Les petits-fils de Clovis, d'Alaric, de Gondebaud, d'Alboïn, de Rollon, parlaient déjà roman. Ce fait était lui-même la conséquence d'une autre particularité importante; c'est que les Francs, les Burgondes, les Goths, les Lombards, les Normands avaient très peu de femmes de leur race avec eux. Pendant plusieurs générations, les chefs ne se marient qu'avec des femmes germaines; mais leurs concubines sont latines, les nourrices des enfants sont latines; toute la tribu épouse des femmes latines; ce qui fit que la lingua francica, la lingua gothica n'eurent, depuis l'établissement des Francs et des Goths en terres romaines, que de très courtes destinées. Il n'en fut pas ainsi en Angleterre; car l'invasion anglo-saxonne avait sans doute des femmes avec elle; la population bretonne s'enfuit, et, d'ailleurs, le latin n'était plus, ou même, ne fut jamais dominant dans la Bretagne. Si on eût généralement parlé gaulois dans la Gaule, au Ve siècle, Clovis et les siens.n'eussent pas abandonné le germanique pour le gaulois.

De là ce résultat capital que, malgré l'extrême violence des moeurs des envahisseurs germains, le moule qu'ils imposèrent devint, avec les siècles, le moule même de la nation. France devint très légitimement le nom d'un pays où il n'était entrée qu'une imperceptible minorité de Francs. Au Xe siècle; dans les premières chansons de geste, qui sont un miroir si parfait de l'esprit du temps, tous les habitants de la France sont des Français: L'idée d'une différence de races dans la population de la France, si évidente chez Grégoire de Tours, ne se présente à aucun degré chez les écrivains et les poètes français postérieurs à Hugues Capet. La différence du noble et du vilain est aussi accentuée que possible; mais la différence de l'un à l'autre n'est en rien une 
différence ethnique; c'est une différence de courage, d'habitudes et d'éducation transmise héréditairement; l'idée que l'origine de tout cela soit une conquête ne vient à personne. Le faux système d'après lequel la noblesse dut son origine à un privilège conféré par le roi pour de grands services rendus à la nation, si bien que tout noble est un anobli, ce système est établi comme un dogme dès le XIIIe siècle. La même chose se passa à la suite de presque toutes les conquêtes normandes. Au bout d'une ou deux générations, les envahisseurs normands ne se distinguaient plus du reste de la population; leur influence n'en avait pas moins été profonde; ils avaient donné au pays conquis une noblesse, des habitudes militaires, un patriotisme qu'il n'avait pas auparavant.

L'oubli, et je dirai même l'erreur historique, sont un facteur essentiel de la création d'une nation, et c'est ainsi que le progrès des études historiques est souvent pour la nationalité un danger. L'investigation historique, en effet, remet en lumière les faits de violence qui se sont passés à l'origine de toutes les formations politiques, même de celles dont les conséquences ont été le plus bienfaisantes. L'unité se fait toujours brutalement; la réunion de la France du Nord et de la France du Midi a été le résultat d'une extermination et d'une terreur continuée pendant près d'un siècle. Le roi de France, qui est, si j'ose le dire, le type idéal d'un cristallisateur séculaire; le roi de France, qui a fait la plus parfaite unité nationale qu'il y ait ; le roi de France, vu de trop près, a perdu son prestige; la nation qu'il avait formée l'a maudit, et, aujourd'hui, il n'y a que les esprits cultivés qui sachent ce qu'il valait et ce qu'il a fait.

C'est par le contraste que ces grandes lois de l'histoire de l'Europe occidentale deviennent sensibles. Dans l'entreprise que le roi de France, en partie par sa tyrannie, en partie par sa justice, a si admirablement menée à terme, beaucoup de pays ont échoué. Sous la couronne de saint Étienne, les Magyars et les Slaves sont restés aussi distincts qu'ils l'étaient il y a huit cents ans. Loin de fondre les éléments divers de ses domaines, la maison de Habsbourg les a tenus distincts et souvent opposés les uns aux autres. En Bohême, l'élément tchèque et l'élément 
allemand sont superposés comme l'huile et l'eau dans un verre. La politique turque de la séparation des nationalités d'après la religion a eu de bien plus graves conséquences: elle a causé la ruine de l'Orient. Prenez une ville comme Salonique ou Smyrne, vous y trouverez cinq ou six communautés dont chacune a ses souvenirs et qui n'ont entre elles presque rien en commun. Or l'essence d'une nation est que tous les individus aient beaucoup de choses en commun, et aussi que tous aient oublié bien des choses. Aucun citoyen français ne sait s'il est burgonde, alain, taïfale, visigoth; tout citoyen français doit avoir oublié la Saint-Barthélemy, les massacres du Midi au XIIIe siècle. Il n'y a pas en France dix familles qui puissent fournir la preuve d'une origine franque, et encore une telle preuve serait-elle essentiellement défectueuse, par suite de mille croisements inconnus qui peuvent déranger tous les systèmes des généalogistes.

La nation moderne est donc un résultat historique amené par une série de faits convergeant dans le même sens. Tantôt l'unité a été réalisée par une dynastie, comme c'est le cas pour la France; tantôt elle l'a été par la volonté directe des provinces, comme c'est le cas pour la Hollande, la Suisse, la Belgique; tantôt par un esprit général, tardivement vainqueur des caprices de la féodalité, comme c'est le cas pour l'Italie et l'Allemagne. Toujours une profonde raison d'être a présidé à ces formations. Les principes, en pareils cas, se font jour par les surprises les plus inattendues. Nous avons vu, de nos jours, l'Italie unifiée par ses défaites, et la Turquie démolie par ses victoires. Chaque défaite avançait les affaires de l'Italie; chaque victoire perdait la Turquie; car l'Italie est une nation, et la Turquie, hors de l'Asie Mineure, n'en est pas une. C'est la gloire de la France d'avoir, par la Révolution française, proclamé qu'une nation existe par elle-même. Nous ne devons pas trouver mauvais qu'on nous imite. Le principe des nations est le nôtre. Mais qu'est-ce donc qu'une nation? Pourquoi la Hollande est-elle une nation, tandis que le Hanovre ou le grandduché de Parme n'en sont pas une? Comment la France persiste-t-elle à être une nation, quand le principe qui l'a créée a disparu? Comment la Suisse, qui a trois langues, deux religions, trois ou quatre races, 
est-elle une nation, quand la Toscane, par exemple, qui est si homogène, n'en est pas une? Pourquoi l'Autriche est-elle un État et non pas une nation? En quoi le principe des nationalités diffère-t-il du principe des races? Voilà des points sur lesquels un esprit réfléchi tient à être fixé, pour se mettre d'accord avec lui-même. Les affaires du monde ne se règlent guère par ces sortes de raisonnements ; mais les hommes appliqués veulent porter en ces matières quelque raison et démêler les confusions où s'embrouillent les esprits superficiels.

\section{III}

À entendre certains théoriciens politiques, une nation est avant tout une dynastie, représentant une ancienne conquête, conquête acceptée d'abord, puis oubliée par la masse du peuple. Selon les politiques dont je parle, le groupement de provinces effectué par une dynastie, par ses guerres, par ses mariages, par ses traités, finit avec la dynastie qui l'a formé. Il est très vrai que la plupart des nations modernes ont été faites par une famille d'origine féodale, qui a contracté mariage avec le sol et qui a été en quelque sorte un noyau de centralisation. Les limites de la France en 1789 n'avaient rien de naturel ni de nécessaire. La large zone que la maison capétienne avait ajoutée à l'étroite lisière du traité de Verdun fut bien l'acquisition personnelle de cette maison. À l'époque où furent faites les annexions, on n'avait l'idée ni des limites naturelles, ni du droit des nations, ni de la volonté des provinces. La réunion de l'Angleterre, de l'Irlande et de l'Écosse fut de même un fait dynastique. L'Italie n'a tardé si longtemps à être une nation que parce que, parmi ses nombreuses maisons régnantes, aucune, avant notre siècle, ne se fit le centre de l'unité. Chose étrange, c'est à l'obscure île de Sardaigne, terre à peine italienne, qu'elle a pris un titre royal. La Hollande, qui s'est créée elle-même, par un acte d'hérö̈que résolution, a néanmoins contracté un mariage intime avec la maison d'Orange, et elle courrait de vrais dangers le jour où cette union serait compromise. 
Une telle loi, cependant, est-elle absolue? Non, sans doute. La Suisse et les États-Unis, qui se sont formés comme des conglomérats d'additions successives, n'ont aucune base dynastique. Je ne discuterai pas la question en ce qui concerne la France. Il faudrait avoir le secret de l'avenir. Disons seulement que cette grande royauté française avait été si hautement nationale, que, le lendemain de sa chute, la nation a pu tenir sans elle. Et puis le XVIIIe siècle avait changé toute chose. L'homme était revenu, après des siècles d'abaissement, à l'esprit antique, au respect de lui-même, à l'idée de ses droits. Les mots de patrie et de citoyen avaient repris leur sens. Ainsi a pu s'accomplir l'opération la plus hardie qui ait été pratiquée dans l'histoire, opération que l'on peut comparer à ce que serait, en physiologie, la tentative de faire vivre en son identité première un corps à qui l'on aurait enlevé le cerveau et le coeur.

Il faut donc admettre qu'une nation peut exister sans principe dynastique, et même que des nations qui ont été formées par des dynasties peuvent se séparer de cette dynastie sans pour cela cesser d'exister. Le vieux principe qui ne tient compte que du droit des princes ne saurait plus être maintenu; outre le droit dynastique, il y a le droit national. Ce droit national, sur quel critérium le fonder? à quel signe le connaître? de quel fait tangible le faire dériver?

\section{$\mathbb{I}$ - De la race, disent plusieurs avec assurance.}

Les divisions artificielles, résultant de la féodalité, des mariages princiers, des congrès de diplomates, sont caduques. Ce qui reste ferme et fixe, c'est la race des populations. Voilà ce qui constitue un droit, une légitimité. La famille germanique, par exemple, selon la théorie que j'expose, a le droit de reprendre les membres épars du germanisme, même quand ces membres ne demandent pas à se rejoindre. Le droit du germanisme sur telle province est plus fort que le droit des habitants de cette province sur eux-mêmes. On crée ainsi une sorte de droit primordial analogue à celui des rois de droit divin; au principe des nations on substitue celui de l'ethnographie. C'est là une très grande 
erreur, qui, si elle devenait dominante, perdrait la civilisation européenne. Autant le principe des nations est juste et légitime, autant celui du droit primordial des races est étroit et plein de danger pour le véritable progrès.

Dans la tribu et la cité antiques, le fait de la race avait, nous le reconnaissons, une importance de premier ordre. La tribu et la cité antiques n'étaient qu'une extension de la famille. À Sparte, à Athènes, tous les citoyens étaient parents à des degrés plus ou moins rapprochés. Il en était de même chez les Beni-Israël; il en est encore ainsi dans les tribus arabes. D'Athènes, de Sparte, de la tribu israélite, transportonsnous dans l'Empire romain. La situation est tout autre. Formée d'abord par la violence, puis maintenue par l'intérêt, cette grande agglomération de villes, de provinces absolument différentes, porte à l'idée de race le coup le plus grave. Le christianisme, avec son caractère universel et absolu, travaille plus efficacement encore dans le même sens. Il contracte avec l'Empire romain une alliance intime, et, par l'effet de ces deux incomparables agents d'unification, la raison ethnographique est écartée du gouvernement des choses humaines pour des siècles.

L'invasion des barbares fut, malgré les apparences, un pas de plus dans cette voie. Les découpures de royaumes barbares n'ont rien d'ethnographique; elles sont réglées par la force ou le caprice des envahisseurs. La race des populations qu'ils subordonnaient était pour eux la chose la plus indifférente. Charlemagne refit à sa manière ce que Rome avait déjà fait: un empire unique composé des races les plus diverses; les auteurs du traité de Verdun, en traçant imperturbablement leurs deux grandes lignes du nord au sud, n'eurent pas le moindre souci de la race des gens qui se trouvaient à droite ou à gauche. Les mouvements de frontière qui s'opérèrent dans la suite du Moyen Âge furent aussi en dehors de toute tendance ethnographique. Si la politique suivie de la maison capétienne est arrivée à grouper à peu près, sous le nom de France, les territoires de l'ancienne Gaule, ce n'est pas là un effet de la tendance qu'auraient eue ces pays à se rejoindre à leurs congénères. Le Dauphiné, la Bresse, 
la Provence, la Franche-Comté ne se souvenaient plus d'une origine commune. Toute conscience gauloise avait péri dès le IIe siècle de notre ère, et ce n'est que par une vue d'érudition que, de nos jours, on a retrouvé rétrospectivement l'individualité du caractère gaulois.

La considération ethnographique n'a donc été pour rien dans la constitution des nations modernes. La France est celtique, ibérique, germanique. L'Allemagne est germanique, celtique et slave. L'Italie est le pays où l'ethnographie est la plus embarrassée. Gaulois, Étrusques, Pélasges, Grecs, sans parler de bien d'autres éléments, s'y croisent dans un indéchiffrable mélange. Les îles Britanniques, dans leur ensemble, offrent un mélange de sang celtique et germain dont les proportions sont singulièrement difficiles à définir.

La vérité est qu'il n'y a pas de race pure et que faire reposer la politique sur l'analyse ethnographique, c'est la faire porter sur une chimère. Les plus nobles pays, l'Angleterre, la France, l'Italie, sont ceux où le sang est le plus mêlé. L'Allemagne fait-elle à cet égard une exception? Est-elle un pays germanique pur? Quelle illusion! Tout le Sud a été gaulois. Tout l'Est, à partir d'Elbe, est slave. Et les parties que l'on prétend réellement pures le sont-elles en effet? Nous touchons ici à un des problèmes sur lesquels il importe le plus de se faire des idées claires et de prévenir les malentendus.

Les discussions sur les races sont interminables, parce que le mot race est pris par les historiens philologues et par les anthropologistes physiologistes dans deux sens tout à fait différents. Pour les anthropologistes, la race a le même sens qu'en zoologie; elle indique une descendance réelle, une parenté par le sang. Or l'étude des langues et de l'histoire ne conduit pas aux mêmes divisions que la physiologie. Les mots des brachycéphales, de dolichocéphales n'ont pas de place en histoire ni en philologie. Dans le groupe humain qui créa les langues et la discipline aryennes, il y avait déjà des brachycéphales et des dolichocéphales. Il en faut dire autant du groupe primitif qui créa les langues et l'institution dites sémitiques. En d'autres termes, les origines zoologiques de l'humanité sont énormément antérieures aux 
origines de la culture, de la civilisation, du langage. Les groupes aryen primitif, sémitique primitif, touranien primitif n'avaient aucune unité physiologique. Ces groupements sont des faits historiques qui ont eu lieu à une certaine époque, mettons il y a quinze ou vingt mille ans, tandis que l'origine zoologique de l'humanité se perd dans des ténèbres incalculables. Ce qu'on appelle philologiquement et historiquement la race germanique est sûrement une famille bien distincte dans l'espèce humaine. Mais est-ce là une famille au sens anthropologique? Non, assurément. L'apparition de l'individualité germanique dans l'histoire ne se fait que très peu de siècles avant Jésus-Christ. Apparemment les Germains ne sont pas sortis de terre à cette époque. Avant cela, fondus avec les Slaves dans la grande masse indistincte des Scythes, ils n'avaient pas leur individualité à part. Un Anglais est bien un type dans l'ensemble de l'humanité. Or le type de ce qu'on appelle très improprement la race anglo-saxonne n'est ni le Breton du temps de César, ni l'Anglo-Saxon de Hengist, ni le Danois de Knut, ni le Normand de Guillaume le Conquérant ; c'est la résultante de tout cela. Le Français n'est ni un Gaulois, ni un Franc, ni un Burgonde. Il est ce qui est sorti de la grande chaudière où, sous la présidence du roi de France, ont fermenté ensemble les éléments les plus divers. Un habitant de Jersey ou de Guernesey ne diffère en rien, pour les origines, de la population normande de la côte voisine. Au XIe siècle, l'oeil le plus pénétrant n'eût pas saisi des deux côtés du canal la plus légère différence. D'insignifiantes circonstances font que PhilippeAuguste ne prend pas ces îles avec le reste de la Normandie. Séparées les unes des autres depuis près de sept cents ans, les deux populations sont devenues non seulement étrangères les unes aux autres, mais tout à fait dissemblables. La race, comme nous l'entendons, nous autres, historiens, est donc quelque chose qui se fait et se défait. L'étude de la race est capitale pour le savant qui s'occupe de l'histoire de l'humanité. Elle n'a pas d'application en politique. La conscience instinctive qui a présidé à la confection de la carte d'Europe n'a tenu aucun compte de la race, et les premières nations de l'Europe sont des nations de sang essentiellement mélangé. 
Le fait de la race, capital à l'origine, va donc toujours perdant de son importance. L'histoire humaine diffère essentiellement de la zoologie. La race n'y est pas tout, comme chez les rongeurs ou les félins, et on n'a pas le droit d'aller par le monde tâter le crâne des gens, puis les prendre à la gorge en leur disant: «Tu es notre sang; tu nous appartiens!» En dehors des caractères anthropologiques, il y a la raison, la justice, le vrai, le beau, qui sont les mêmes pour tous. Tenez, cette politique ethnographique n'est pas sûre. Vous l'exploitez aujourd'hui contre les autres; puis vous la voyez se tourner contre vous-mêmes. Est-il certain que les Allemands, qui ont élevé si haut le drapeau de l'ethnographie, ne verront pas les Slaves venir analyser, à leur tour, les noms des villages de la Saxe et de la Lusace, rechercher les traces des Wiltzes ou des Obotrites, et demander compte des massacres et des ventes en masse que les Othons firent de leurs aïeux? Pour tous il est bon de savoir oublier.

J'aime beaucoup l'ethnographie; c'est une science d'un rare intérêt ; mais, comme je la veux libre, je la veux sans application politique. En ethnographie, comme dans toutes les études, les systèmes changent; c'est la condition du progrès. Les limites des États suivraient les fluctuations de la science. Le patriotisme dépendrait d'une dissertation plus ou moins paradoxale. On viendrait dire au patriote: «Vous vous trompiez; vous versiez votre sang pour telle cause; vous croyiez être celte ; non, vous êtes germain». Puis, dix ans après, on viendra vous dire que vous êtes slave. Pour ne pas fausser la science, dispensons-la de donner un avis dans ces problèmes, où sont engagés tant d'intérêts. Soyez sûrs que, si on la charge de fournir des éléments à la diplomatie, on la surprendra bien des fois en flagrant délit de complaisance. Elle a mieux à faire: demandons-lui tout simplement la vérité.

III. - Ce que nous venons de dire de la race, il faut le dire de la langue.

La langue invite à se réunir; elle n'y force pas. Les États-Unis et l'Angleterre, l'Amérique espagnole et l'Espagne parlent la même 
langue et ne forment pas une seule nation. Au contraire, la Suisse, si bien faite, puisqu'elle a été faite par l'assentiment de ses différentes parties, compte trois ou quatre langues. Il y a dans l'homme quelque chose de supérieur à la langue : c'est la volonté. La volonté de la Suisse d'être unie, malgré la variété de ses idiomes, est un fait bien plus important qu'une similitude souvent obtenue par des vexations.

Un fait honorable pour la France, c'est qu'elle n'a jamais cherché à obtenir l'unité de la langue par des mesures de coercition. Ne peuton pas avoir les mêmes sentiments et les mêmes pensées, aimer les mêmes choses en des langages différents? Nous parlions tout à l'heure de l'inconvénient qu'il y aurait à faire dépendre la politique internationale de l'ethnographie. Il n'y en aurait pas moins à la faire dépendre de la philologie comparée. Laissons à ces intéressantes études l'entière liberté de leurs discussions; ne les mêlons pas à ce qui en altérerait la sérénité. L'importance politique qu'on attache aux langues vient de ce qu'on les regarde comme des signes de race. Rien de plus faux. La Prusse, où l'on ne parle plus qu'allemand, parlait slave il y a quelques siècles; le pays de Galles parle anglais; la Gaule et l'Espagne parlent l'idiome primitif d'Albe la Longue ; l'Égypte parle arabe; les exemples sont innombrables. Même aux origines, la similitude de langue n'entraînait pas la similitude de race. Prenons la tribu protoaryenne ou proto-sémite; il s'y trouvait des esclaves, qui parlaient la même langue que leurs maîtres; or l'esclave était alors bien souvent d'une race différente de celle de son maître. Répétons-le: ces divisions de langues indo-européennes, sémitiques et autres, créées avec une si admirable sagacité par la philologie comparée, ne coüncident pas avec les divisions de l'anthropologie. Les langues sont des formations historiques, qui indiquent peu de choses sur le sang de ceux qui les parlent, et qui, en tout cas, ne sauraient enchaîner la liberté humaine quand il s'agit de déterminer la famille avec laquelle on s'unit pour la vie et pour la mort.

Cette considération exclusive de la langue a, comme l'attention trop forte donnée à la race, ses dangers, ses inconvénients. Quand on 
y met de l'exagération, on se renferme dans une culture déterminée, tenue pour nationale; on se limite, on se claquemure. On quitte le grand air qu'on respire dans le vaste champ de l'humanité pour s'enfermer dans des conventicules de compatriotes. Rien de plus mauvais pour l'esprit; rien de plus fâcheux pour la civilisation. $N$ 'abandonnons pas ce principe fondamental, que l'homme est un être raisonnable et moral, avant d'être parqué dans telle ou telle langue, avant d'être un membre de telle ou telle race, un adhérent de telle ou telle culture. Avant la culture française, la culture allemande, la culture italienne, il y a la culture humaine. Voyez les grands hommes de la Renaissance; ils n'étaient ni français, ni italiens, ni allemands. Ils avaient retrouvé, par leur commerce avec l'antiquité, le secret de l'éducation véritable de l'esprit humain, et ils s'y dévouaient corps et âme. Comme ils firent bien!

\section{III - La religion ne saurait non plus offrir une base suffisante à l'établissement d'une nationalité moderne.}

À l'origine, la religion tenait à l'existence même du groupe social. Le groupe social était une extension de la famille. La religion, les rites étaient des rites de famille. La religion d'Athènes, c'était le culte d'Athènes même, de ses fondateurs mythiques, de ses lois, de ses usages. Elle n'impliquait aucune théologie dogmatique. Cette religion était, dans toute la force du terme, une religion d'État. On n'était pas athénien si on refusait de la pratiquer. C'était au fond le culte de l'Acropole personnifiée. Jurer sur l'autel d'Aglaure, c'était prêter le serment de mourir pour la patrie. Cette religion était l'équivalent de ce qu'est chez nous l'acte de tirer au sort, ou le culte du drapeau. Refuser de participer à un tel culte était comme serait dans nos sociétés modernes refuser le service militaire. C'était déclarer qu'on n'était pas athénien. D'un autre côté, il est clair qu'un tel culte n'avait pas de sens pour celui qui n'était pas d'Athènes ; aussi n'exerçait-on aucun prosélytisme pour forcer des étrangers à l'accepter; les esclaves 
d'Athènes ne le pratiquaient pas. Il en fut de même dans quelques petites républiques du Moyen Âge. On n'était pas bon vénitien si l'on ne jurait point par saint Marc; on n'était pas bon amalfitain si l'on ne mettait pas saint André au-dessus de tous les autres saints du paradis. Dans ces petites sociétés, ce qui a été plus tard persécution, tyrannie, était légitime et tirait aussi peu à conséquence que le fait chez nous de souhaiter la fête au père de famille et de lui adresser des voeux au premier jour de l'an.

Ce qui était vrai à Sparte, à Athènes, ne l'était déjà plus dans les royaumes sortis de la conquête d'Alexandre, ne l'était surtout plus dans l'Empire romain. Les persécutions d'Antiochus Épiphane pour amener l'Orient au culte de Jupiter Olympien, celles de l'Empire romain pour maintenir une prétendue religion d'État furent une faute, un crime, une véritable absurdité. De nos jours, la situation est parfaitement claire. Il n'y a plus de masses croyant d'une manière uniforme. Chacun croit et pratique à sa guise, ce qu'il peut, comme il veut. Il n'y a plus de religion d'État; on peut être français, anglais, allemand, en étant catholique, protestant, israélite, en ne pratiquant aucun culte. La religion est devenue chose individuelle; elle regarde la conscience de chacun. La division des nations en catholiques, protestantes, n'existe plus. La religion, qui, il y a cinquante-deux ans, était un élément si considérable dans la formation de la Belgique, garde toute son importance dans le for intérieur de chacun; mais elle est sortie presque entièrement des raisons qui tracent les limites des peuples.

\section{IV - La commumauté des intérêts est assurément un lien puissant entre les hommes.}

Les intérêts, cependant, suffisent-ils à faire une nation? Je ne le crois pas. La communauté des intérêts fait les traités de commerce. Il y a dans la nationalité un côté de sentiment; elle est âme et corps à la fois; un Zollverein n'est pas une patrie. 


\section{V - La géographie, ce qu'on appelle les frontières maturelles, a} certaimement une part considérable dans la division des nations.

La géographie est un des facteurs essentiels de l'histoire. Les rivières ont conduit les races; les montagnes les ont arrêtées. Les premières ont favorisé, les secondes ont limité les mouvements historiques. Peut-on dire cependant, comme le croient certains partis, que les limites d'une nation sont écrites sur la carte et que cette nation a le droit de s'adjuger ce qui est nécessaire pour arrondir certains contours, pour atteindre telle montagne, telle rivière, à laquelle on prête une sorte de faculté limitante a priori? Je ne connais pas de doctrine plus arbitraire ni plus funeste. Avec cela, on justifie toutes les violences. Et, d'abord, sont-ce les montagnes ou bien sont-ce les rivières qui forment ces prétendues frontières naturelles? Il est incontestable que les montagnes séparent ; mais les fleuves réunissent plutôt. Et puis toutes les montagnes ne sauraient découper des États. Quelles sont celles qui séparent et celles qui ne séparent pas? De Biarritz à Tornea, il n'y a pas une embouchure de fleuve qui ait plus qu'une autre un caractère bornal. Si l'histoire l'avait voulu, la Loire, la Seine, la Meuse, l'Elbe, l'Oder auraient, autant que le Rhin, ce caractère de frontière naturelle qui a fait commettre tant d'infractions au droit fondamental, qui est la volonté des hommes. On parle de raisons stratégiques. Rien n'est absolu; il est clair que bien des concessions doivent être faites à la nécessité. Mais il ne faut pas que ces concessions aillent trop loin. Autrement, tout le monde réclamera ses convenances militaires, et ce sera la guerre sans fin. Non, ce n'est pas la terre plus que la race qui fait une nation. La terre fournit le substratum, le champ de la lutte et du travail; l'homme fournit l'âme. L'homme est tout dans la formation de cette chose sacrée qu'on appelle un peuple. Rien de matériel n'y suffit. Une nation est un principe spirituel, résultant des complications profondes de l'histoire, une famille spirituelle, non un groupe déterminé par la configuration du sol. 
Nous venons de voir ce qui ne suffit pas à créer un tel principe spirituel: la race, la langue, les intérêts, l'affinité religieuse, la géographie, les nécessités militaires. Que faut-il donc en plus? Par suite de ce qui a été dit antérieurement, je n'aurai pas désormais à retenir bien longtemps votre attention.

\section{III}

Une nation est une âme, un principe spirituel. Deux choses qui, à vrai dire, n'en font qu'une, constituent cette âme, ce principe spirituel. L'une est dans le passé, l'autre dans le présent. L'une est la possession en commun d'un riche legs de souvenirs; l'autre est le consentement actuel, le désir de vivre ensemble, la volonté de continuer ă faire valoir l'héritage qu'on a reçu indivis. L'homme, Messieurs, ne s'improvise pas. La nation, comme l'individu, est l'aboutissant d'un long passé d'efforts, de sacrifices et de dévouements. Le culte des ancêtres est de tous le plus légitime; les ancêtres nous ont faits ce que nous sommes. Un passé héroïque, des grands hommes, de la gloire (j'entends de la véritable), voilà le capital social sur lequel on assied une idée nationale. Avoir des gloires communes dans la passé, une volonté commune dans le présent; avoir fait de grandes choses ensemble, vouloir en faire encore, voilà les conditions essentielles pour être un peuple. On aime en proportion des sacrifices qu'on a consentis, des maux qu'on a soufferts. On aime la maison qu'on a bâtie et qu'on transmet. Le chant spartiate : «Nous sommes ce que vous fûtes; nous serons ce que vous êtes» est dans sa simplicité l'hymne abrégé de toute patrie.

Dans le passé, un héritage de gloire et de regrets à partager, dans l'avenir un même programme à réaliser; avoir souffert, joui, espéré ensemble, voilà ce qui vaut mieux que des douanes communes et des frontières conformes aux idées stratégiques; voilà ce que l'on comprend malgré les diversités de race et de langue. Je disais tout à l'heure: «avoir souffert ensemble»; oui, la souffrance en commun unit plus que la joie. En fait de souvenirs nationaux, les deuils valent mieux que les triomphes, car ils imposent des devoirs, ils commandent l'effort en commun. 
Une nation est donc une grande solidarité, constituée par le sentiment des sacrifices qu'on a faits et de ceux qu'on est disposé à faire encore. Elle suppose un passé; elle se résume pourtant dans le présent par un fait tangible: le consentement, le désir clairement exprimé de continuer la vie commune. L'existence d'une nation est (pardonnez-moi cette métaphore) un plébiscite de tous les jours, comme l'existence de l'individu est une affirmation perpétuelle de vie. Oh! je le sais, cela est moins métaphysique que le droit divin, moins brutal que le droit prétendu historique. Dans l'ordre d'idées que je vous soumets, une nation n'a pas plus qu'un roi le droit de dire à une province: «Tu m'appartiens, je te prends». Une province, pour nous, ce sont ses habitants; si quelqu'un en cette affaire a droit d'être consulté, c'est l'habitant. Une nation n'a jamais un véritable intérêt à s'annexer ou à retenir un pays malgré lui. Le voeu des nations est, en définitive, le seul critérium légitime, celui auquel il faut toujours en revenir.

Nous avons chassé de la politique les abstractions métaphysiques et théologiques. Que reste-t-il, après cela? Il reste l'homme, ses désirs, ses besoins. La sécession, me direz-vous, et, à la longue, l'émiettement des nations sont la conséquence d'un système qui met ces vieux organismes à la merci de volontés souvent peu éclairées. Il est clair qu'en pareille matière aucun principe ne doit être poussé à l'excès. Les vérités de cet ordre ne sont applicables que dans leur ensemble et d'une façon très générale. Les volontés humaines changent ; mais qu'est-ce qui ne change pas ici-bas? Les nations ne sont pas quelque chose d'éternel. Elles ont commencé, elles finiront. La confédération européenne, probablement, les remplacera. Mais telle n'est pas la loi du siècle où nous vivons. À l'heure présente, l'existence des nations est bonne, nécessaire même. Leur existence est la garantie de la liberté, qui serait perdue si le monde n'avait qu'une loi et qu'un maître.

Par leurs facultés diverses, souvent opposées, les nations servent à l'oeuvre commune de la civilisation; toutes apportent une note à ce grand concert de l'humanité, qui, en somme, est la plus haute réalité idéale que nous atteignions. Isolées, elles ont leurs parties faibles. Je 
me dis souvent qu'un individu qui aurait les défauts tenus chez les nations pour des qualités, qui se nourrirait de vaine gloire; qui serait à ce point jaloux, égoïste, querelleur; qui ne pourrait rien supporter sans dégainer, serait le plus insupportable des hommes. Mais toutes ces dissonances de détail disparaissent dans l'ensemble. Pauvre humanité, que tu as souffert! que d'épreuves t'attendent encore ! Puisse l'esprit de sagesse te guider pour te préserver des innombrables dangers dont ta route est semée!

Je me résume, Messieurs. L'homme n'est esclave ni de sa race, ni de sa langue, ni de sa religion, ni du cours des fleuves, ni de la direction des chaînes de montagnes. Une grande agrégation d'hommes, saine d'esprit et chaude de coeur, crée une conscience morale qui s'appelle une nation. Tant que cette conscience morale prouve sa force par les sacrifices qu'exige l'abdication de l'individu au profit d'une communauté, elle est légitime, elle a le droit d'exister. Si des doutes s'élèvent sur ses frontières, consultez les populations disputées. Elles ont bien le droit d'avoir un avis dans la question. Voilà qui fera sourire les transcendants de la politique, ces infaillibles qui passent leur vie à se tromper et qui, du haut de leurs principes supérieurs, prennent en pitié notre terre à terre. «Consulter les populations, fi donc! quelle naïveté! Voilà bien ces chétives idées françaises qui prétendent remplacer la diplomatie et la guerre par des moyens d'une simplicité enfantine». Attendons, Messieurs; laissons passer le règne des transcendants; sachons subir le dédain des forts. Peut-être, après bien des tâtonnements infructueux, reviendra-t-on à nos modestes solutions empiriques. Le moyen d'avoir raison dans l'avenir est, à certaines heures, de savoir se résigner à être démodé.

ERNEST, Renan. Qu'est-ce qu'une Nation? 1882. Saisie du texte: S. Pestel pour la collection électronique de la Bibliothèque Municipale de Lisieux (17.02.1997). http://ourworld.compuserve. $\mathrm{com} /$ homepages/bib_lisieux/nation01.htm 